\title{
Polar Geography
}

\section{Introduction: feminist approaches and the study of gender in Arctic social sciences}

\section{Vladislava Vladimirova \& J. Otto Habeck}

To cite this article: Vladislava Vladimirova \& J. Otto Habeck (2018) Introduction: feminist approaches and the study of gender in Arctic social sciences, Polar Geography, 41:3, 145-163, DOI: $10.1080 / 1088937 X .2018 .1496368$

To link to this article: https://doi.org/10.1080/1088937X.2018.1496368

\section{Published online: 14 Aug 2018.}

Submit your article to this journal $\sqsubset$

山 Article views: 227

Q View related articles $\sqsubset$

View Crossmark data \lceil

Citing articles: 1 View citing articles 


\title{
Introduction: feminist approaches and the study of gender in Arctic social sciences
}

\author{
Vladislava Vladimirova (1) and J. Otto Habeck \\ Faculty of Humanities, Institute for Social and Cultural Anthropology, Universität Hamburg, Hamburg, \\ Germany
}

\begin{abstract}
Notwithstanding the gradual intensification of contacts across the different parts of the circumpolar North, research on gender in the Arctic is still a fragmented field - not the least because of language barriers. The four cases presented here, all from the Far North of Russia, are intended to complement research on gender in North America and the Nordic countries. We also hope they will encourage wider use of feminist approaches in geography and social sciences. After a first overview of how gender emerged as a topic of study in the circumpolar North, the introduction will focus on gender-specific forms of mobility and immobility. Next, gender will be discussed in relation to identity and intersectionality under colonial and post-colonial conditions. Thereafter, Feminist Political Ecology and other theoretical directions are portrayed as theoretical approaches to studying gendered economies. Such contextualization of the study of gender in the Arctic prepares the ground for short summaries of the four papers in this special issue, to be concluded by a brief statement about future directions of research. Particularly the concept of intersectionality is favored as a useful basis for examining gender, indigeneity, and economic differences.
\end{abstract}

\section{ARTICLE HISTORY}

Received 24 June 2018

Accepted 30 June 2018

\section{KEYWORDS}

Gender; indigeneity; intersectionality; feminist approaches in geography and anthropology

Up until very recently, the topic of gender did not figure prominently in Arctic research. As one colleague observed with reference to a large and interdisciplinary event - the UArctic Congress - in 2016: 'Though it would be unfair to claim that absolutely no one included gender insights and analysis into their research presentations at that event, [...] gender was not central or key to many or most research projects' (Hoogensen Gjørv, 2017, p. 293). That gender has been a rather neglected theme in Arctic research can be attributed to the latter's particular history and agenda, as will be argued in this introduction. Obviously, though, any research on how resources are distributed and used, how space is organized, and how places attain particular meanings, will strongly benefit from a gendered perspective.

Most immediately, the necessity and advantages of such an approach come to the fore when analysing demographic processes, migration and mobility, distribution of labor and livelihoods. Perhaps less in the limelight of Polar research thus far, but not less pervasive, are changes in practices and policies of social support, care, and education, social and 
community life, kinship and family relations. A further domain in which a gendered approach offers new insights is the study of shifts in political leadership and representations of indigeneity. The interplay of all these domains is informed by norms and stereotypes about female and male behavior, which constitute a topic of study in their own right. A comprehensive approach to studying gender in Arctic and Sub-Arctic communities should identify past changes and future trends in all of these domains. The task of this special issue of Polar Geography by necessity must have a somewhat more modest aim: it is to provide an introduction into social-sciences scholarship on gender as a research topic in this specific region, and to offer case studies that exemplify the multitude of processes at work.

We hope that the four cases presented here, all from the Far North of Russia, will complement research on gender in North America and the Nordic countries. We also hope they will encourage wider use of feminist approaches in geography and social sciences. Feminist scholarship in geography, anthropology and related fields attained growing influence from the 1970s onwards (Domosh, 1991; Massey, 1994; Moore, 1988; Strathern, 1987), but it was mainly over the last two decades that feminist approaches came to be applied in research in the Arctic.

In order to state our points, we will proceed as follows: after a first overview of how gender emerged as a topic of study in the circumpolar North, the next section will focus on gender-specific forms of mobility and immobility. Following on from that, gender will be discussed in relation to identity and intersectionality under colonial and post-colonial conditions. Thereafter, Feminist Political Ecology and other theoretical directions are portrayed as theoretical approaches to the study of gendered economies. Such contextualization of the study of gender in the Arctic prepares the ground for short summaries of the four papers in this special issue, to be concluded by a brief statement about future directions of research.

\section{The emergence of gender as a topic of study in the circumpolar North}

We take Russia as starting point for an overview of gender as topic of study in Arctic social sciences. One of the pioneers of feminist scholarship in the Russian North is Marjorie Balzer who in the early 1980s - at a time when opportunities for non-Soviet scholars to conduct ethnographic fieldwork were still highly limited - started a long-term research interest in gender identities and ritual among the Siberian Khanty (Balzer, 1981, 1996). Such research clearly departed from earlier ethnographic interest in sex and gender which reflected older epistemologies, often following an evolutionist paradigm and harking back to Frederick Engels's study on property, power, and division of labor among the sexes in different societies (Engels, 1902). We should not ignore in this brief review the impressive range of Soviet ethnographic contributions, embodied by such prolific and influential scholars with extensive fieldwork experience as Liudmila V. Khomich (1950, 1985), Glafira M. Vasilevich (1969), and Tat'iana I. Luk'ianchenko (1971), to mention only a few.

Soviet scholarship was inspired by Soviet feminism and emancipatory ideology; its analyses were shaped by critical views on traditional social structures that were seen as oppressive to women, as for example bridewealth, levirate, and male ownership over the means of production. A critical history of Soviet thought in the social sciences and its contribution 
to Gender Studies is yet to be written. Nevertheless, Soviet scholarship, in its scope and limits of interest in gender relations, shows remarkable parallels with research elsewhere, expectedly within Marxist inspired anthropology (Leacock, 1983): women were studied predominantly in connection to kinship institutions, marriage, family relations, and reproduction, and finally the home and material objects related to it. Such spheres of traditional academic interest in women's roles and status have served as a departure point for the criticism that gave rise to feminist scholarship in geography (Laliberte, DriscollDerickson, \& Dowler, 2017) and anthropology (Morgen, 1989; Reiter, 1975; Rosaldo, Lamphere, \& Bamberger, 1974) since the 1970s.

In the North American and North European part of the Arctic, research on gender relations also emerged in the late 1970s and 1980s, notably in anthropology. For example, Barbara Bodenhorn (1990, 1993) substantially raised awareness about women's participation in Alaskan Iñupiat hunting practices; Hugh Beach examined how Swedish reindeer herding legislation established subjected positions of Sámi women in relation to reindeer-herding resources and the manifold indigenous land-use rights that are bound to the latter (Beach, 1982); and Myrdene Anderson provided an early analysis of the gendered 'division of production, distribution and consumption in Saami society' (Anderson, 1987). Her study of the Kautokeino reindeer-herding community stressed the central role of women in preserving a diversified Sámi subsistence economy in the face of leveling market-propelled pressures.

It should be underlined that until a decade ago, Arctic social-sciences studies usually did not engage (and seemed to be quite unaware of) feminist thought, since the latter has a different genealogy: feminist scholarship in geography emerged from gender and development studies, which had little influence on earlier Arctic research. The late entry of Arctic gender research still awaits a thorough analysis, but clearly it is related to a few perennial tropes in the diverse and complex representations of the North: first, the Arctic as a remote world of mysterious beauty, purity and simultaneously of implacable harshness (Potter, 2007); later, during the modernist project of mastering nature (McCauley, 2014; Richter, 1997), the imagery of Arctic exploration, focusing on the human toll and on heroism became exuberant (Frank, 2011).

The circumpolar countries' modernist agendas not only exerted considerable influence on ethnographic research, but also emphasized certain topics and representational styles in Arctic scholarship (Bravo \& Sörlin, 2002; Doel, Friedman, Lajus, Sörlin, \& Wråkberg, 2014), while avoiding or repressing other themes and styles. To take the Soviet Union as an example, its ideology of progress predefined a particular temporal framing of research, whereby religious practice and kinship were presented in past tense and carried negative connotations of backwardness and underdevelopment, while economy, education, and technological innovation were described in present and future tense and attained positive connotations. No need to say that the latter spheres were highlighted as achievements of Soviet modernization. This temporal schema criss-crossed with a spatial arrangement that can be graphically presented along the binary of wilderness (tundra and taiga) vs. civilization (town and village). Some of the big themes of socialsciences research, such as religion or kinship, had a simple location, namely in the past and the wilderness. Others, such as economy, show a more complex positioning in this system of coordinates, by being located in both wilderness and town, and undergoing a positive transformation from the past to the future. Women, thus, and research on 
them, were presented within two main coordinates: past and wilderness, and present/ future and urbanization/civilization.

Furthermore, we can see a strong male bias in research on the Arctic, which has long been associated in the popular imagination as a domain of heroic feats of hardy explorers, or as a production area where male workers master and harvest resources from the wilderness, be it minerals, metals, oil or reindeer meat and fish (Bloom, Glasberg, \& Kay, 2008; Habeck, 2005b; Rosner, 2009). We believe, however, that the debate is already moving beyond such stereotypes and structural limitations.

All fields of science and humanities in the circumpolar North have seen major changes in the way women and other previously underrepresented groups, such as indigenous scholars for example, have come to participate in research and shape research agendas. To be sure, more effort is needed to accomplish equal participation of women and men in Polar sciences, but the overall trend is encouraging. The collection of articles in this special issue strikes a good balance between male and female scholars; in addition, the national and academic background of the scholars is diverse, but with a clear presence of less-represented schools, such as Eastern European.

From our point of view, underrepresentation of women in research on the Arctic continues to pose significant problems. Not less worrying, however, are: the fragmentation of scholarly debate in different parts of the circumpolar North; the comparatively weak interface of academic and local stakeholders' interests; and the complex relation between indigenous and non-indigenous perspectives on social and environmental change in the Arctic - along with the question of how to endorse indigenous scholarship and communitydriven or participatory research. As Desbiens (2007, p. 364) phrases it, 'For decades, Aboriginal populations in Canada and elsewhere have claimed their rightful place in research as active subjects rather than objects of inquiries'.

When speaking about research on gender in the Arctic, we continually encounter a marked partition between the Russian Federation, Sápmi and the Nordic states, and Canada and Alaska. The language barrier between Russian and English is still looming large. Clearly, indigenous languages of the Arctic criss-cross nation-states' boundaries. Clearly, indigenous organizations cooperate in transnational forums and organizations. And yet, we see a rather low degree of communication between communities (indigenous and non-indigenous alike) in the Far North of Russia with those in Alaska, Canada, and the Nordic countries. The same can be said with regard to scholars working in different parts of the circumpolar North, with a few encouraging exceptions listed further below.

What this special issue of Polar Geography may hopefully achieve, then, is to portray how gender positions and gendered practices shape aspirations and life conditions in indigenous communities across the North of the Russian Federation. Our introduction serves to show how the following contributions are informed by, and feed back into, a broader circumpolar perspective. The articles of this special issue are regionally grounded in the Barents Region (Konstantinov, 2005; Vladimirova, 2006) and the Republic of Sakha Yakutia (Khlinovskaya Rockhill \& Tarasova; Ventsel). Within the overall context of post-socialist transformations, our authors address the following bundle of issues: the tenacity of gendered partitioning of rural spaces; shifting norms of masculinity in the urban sphere; the complex institutional landscape of child-care superseding the Soviet state's practices and ideologies of care that had transformed kinship and family life in 
nomadic communities; and the idea that new reproduction technologies may become part of an indigenous nation-building project.

\section{Gender-specific migration from rural to urban: a pan-Arctic phenomenon?}

'Female flight' - or more exactly speaking, the higher share of women in out-migration from small (rural) communities to larger settlements and onwards to towns and cities has been observed since the early 1990s not only in Alaska (Hamilton \& Seyfrit, 1993; Huskey \& Howe, 2006) but in many parts of the circumpolar North (Dahlström, 1996; Hamilton, Rasmussen, Flanders, \& Seyfrit, 1996; Heleniak, 2015; Rasmussen, 2009; Walsh, Valestrand, Gerrard, \& Aure, 2013). For example, Eikjok's study of gender aspects in Norwegian Sámi reindeer-herding communities reveals that urbanizing tendencies bring about differential roles for Sámi men and women, positioning men as 'losers' in this process (Eikjok, 2007). Gender-differential out-migration from Northern communities has been repeatedly discussed also in this journal, e.g. in a special issue of Polar Geography on migration in Alaska and Russia (Edwards, 2009). Scholars point out the wider challenges of gender-specific out-migration that many communities have to cope with, such as enforced celibacy and higher divorce rates, decreasing population numbers, masculinization of jobs or conversion to short-term shift employment. These challenges are aggravated by widespread phenomena of self-harming behavior (substance abuse and suicide) and interpersonal violence (Istomin, 2012; Josh Snodgrass, 2013; Omma, Sandlund, \& Jacobsson, 2013; Pika \& Bogoyavlensky, 1995; Pika, Davis, \& Krupnik, 1993; Richards, 2004; Vakhtin, 1992).

However, a recent article by Dowsley and Southcott (2017) reveals significant regional differences in gender-specific out-migration. In contrast to Alaska and Greenland, Nunavut is characterized by a stable presence of women in small and medium-sized settlements: 'data suggest that female flight is not a demographic concern in the region' (Dowsley \& Southcott, 2017, p. 11). What can be learnt from the authors' discussion of possible reasons are two insights at least. Firstly, the decision about leaving the community for higher education often depends on the probability to find an adequately well-paid job on return. It is just one piece in the larger mosaic of subsistence work, wage labor and state welfare benefits (and, not to the least, individual arrangements in the field of care and familial support). Secondly, the pressure to leave the community for higher education may diminish thanks to opportunities for distant learning and new communication technologies. More generally, technological change also enables easier communication across communities within and beyond Nunavut, possibly leading to more optimism as to community well-being and development (Dowsley \& Southcott, 2017, p. 15).

The phenomenon of gender-specific out-migration has also been described for many parts of the Russian Federation. Some of its specifics are: a pronounced spatial, administrative and economic transformation of indigenous livelihoods as part of past and ongoing modernization projects, along with a particularly strong connotation of pedagogical and other public-sector jobs with female work. Indigenous women were among the main target groups during the early stage of the Soviet modernization project which promoted transition to a sedentary lifestyle, collectivization, relocation to central settlements with schools, hospitals, and other pertinent infrastructure. Several authors have directly examined the cultural production of gender in the North under Soviet rule (e.g. Sablin \& 
Savelyeva, 2015; Slezkine, 1994; Ssorin-Chaikov, 2003). The problematic - some would say: disruptive - impact of Soviet collectivization on indigenous families has been compellingly presented in many studies (Balzer, 1992, 1999; Bloch, 2003, 2005; Fondahl, 1998; Gernet, 2012; Gray, 2005; Habeck, 2005b; Kerttula, 2000; Konstantinov, 2015; Kuoljok, 1985; Kwon, 1997; Rethmann, 2010; Tuisku, 2001; Vitebsky, 2010; Vitebsky \& Wolfe, 2001; Vladimirova, 2006). This development has led to marked demographic, economic and symbolic shifts in gender relations in the Far North of Russia (Povoroznyuk, Habeck, \& Vaté, 2010) with women being symbolically confined to the villages and towns, whereas the vast spaces of tundra and taiga have turned into predominantly male spaces.

Similar to North America, a regionally differentiated analysis is needed for the North of Russia. Some regions of Russia are reported to differ from the general picture: notably Yamal Peninsula, where the gendered partitioning of space is not strongly perceived (if at all) as reindeer-herding families pragmatically utilize resources of the settlement school, state-provided healthcare - and yet continue to maintain a fully nomadic life. Based on research on Yamal, Liarskaya $(2009,2010,2013)$ reveals the greater variety in life choices that indigenous people gain through education and enskillment in both traditional subsistence practices and centralized professional education provided by the state.

\section{Gender, identity, and intersectionality under (post-)colonial conditions}

The question of identity in the North became important for scholars, politicians, and activists in the early 1990s, when indigenous ethnic groups received much attention within Russia and internationally. Russia inherited this preoccupation with ethnic identity from other parts of the North, where indigenous peoples' movements had been already strong for a couple of decades by then. We have no space to review pertinent literature on identity here, but it must be mentioned that within this thematic field, scholars paid attention to gendered identities too, especially in relation to political activities (female predominance in ethnic activism) and economic ones (male predominance in traditional economies like reindeer husbandry and hunting). As was pointed out in the previous section, spatial and cultural divisions in relation to gender became the subject of discussion in the 1980s and 1990s, like women's absence from tundra and taiga hunters' and herders' camps and economic activities that are perceived as 'uncultured' and men's preference for the latter, as locus of masculine identities. This analysis - even though predominantly concerned with indigenous people - has also sought to situate such phenomena within the general context of Russian and Soviet social history. Proletarian masculinity (Friedman \& Healey, 2002, p. 226; Ventsel, this issue) went hand in hand with the emancipation of women in the Soviet North. Proletarian masculinity may be interpreted as the other side of the coin of socialist women's emancipation: though they seem to contradict each other, they are part of the same social structures.

The debate about the spatial and cultural characteristics of gender identities is intertwined with another discussion that takes for a starting point the uneasy concept of 'tradition'. Indigenous peoples in the Far North of the Russian Federation have long been portrayed in Western literature as traditional in terms of land use, division of labor, and gender roles. Soviet ethnographic scholarship conveyed more complex representations, as the Soviet state simultaneously sought to legitimise its patronizing policies 
and to modernize Northern minority groups. Hence Soviet literature meddled between descriptions of poverty and backwardness, and successes in modernization. The notion of tradition had simultaneously negative connotations - as in descriptions of resistant social and cultural patterns associated with backwardness - and positive when attributed to material and folklore heritage displayed in a controlled way in museums and performed in cultural institutions (Habeck, 2005a). An allegedly traditional division of female vs male norms of behavior is enacted, for example, in some ethnic holiday camps organized by indigenous pedagogues (Schröder, 2016). In the context of the Russian North as represented retrospectively in the 1990s, 'authentic' tradition came to be symbolically tied to economic activities, such as herding and hunting, while urban space and its civilizing institutions - to culture. In this picture, thus, the space of tradition carries male connotations, whereas the space of culture carries female ones. This spatial divide between genders in many parts of the circumpolar North has certain dissonances with earlier (mainly structuralist) approaches in anthropology, where women were seen as symbolically connected to the home and hearth and hence to tradition, while men - to public spaces, politics, decision-taking and implicitly, social change (Bourdieu, 1979). On the other hand, anthropologists have questioned the universal analytical value being attributed to this divide since the 1970s (Ortner, 1996).

Only recently did social scientists start asking: in which ways have colonial regimes or modernization projects brought forward stricter definitions of gender roles and division of labor? It may be too facile to state that gender arrangements were generally more flexible in earlier days; however, for the Russian North, there is evidence that hunting and other forms of 'roaming' the land were pursued by women and men alike (Ssorin-Chaikov, 2003; Ziker, 2010).

A strand of research that deserves special attention in its potential to generate new contributions to ongoing debates on tradition are Feminist Indigenous Studies, which have produced some strong analysis of the misrepresentations that colonial epistemologies have imposed about the role of women and gender relations in indigenous communities (Green, 2007). For example, such research shows how hegemonic discourses connect Sámi women to ideas of authenticity and traditionalism and depict traditional Sámi societies as featuring more equal gender relations (Hernández Rejón, 2016, p. 66). As Jorunn Eikjok explains, such hegemonic discourses work as a source of new contradictions and oppression against Sámi women, and for indigenous society as a whole. Eikjok appeals to scholars to study such colonial discourses in order to reveal the genealogy of gender roles in indigenous communities and explore them as a part of the effects that colonization has had in the regulation of indigenous societies. She admits that patriarchal structures existed among Sámi, but the introduction of a particular modern masculine power has created new forms of oppression against indigenous women, both from inside and outside (Eikjok, 2007).

Other representatives of this strand of research, for example Julie Bettie, point out the intersections of gender and class. The failure to see racial/ethnic subjects as gendered has led to the production of rather simplistic analysis (Bettie, 2000). The concept of intersectionality - here briefly defined as the experience of different forms of discrimination that in their coincidence produce double or multiple marginal positions - is now being increasingly applied in Feminist Indigenous Studies. The recurring issues of indigenous political presentation, gendered aspects of salaried and domestic work, but also the thorny topic of 
violence against women have recently been tied together in the writings of Rauna Kuokkanen $(2007,2015)$. Kuokkanen is one of the few scholars who explicitly draws comparisons between indigenous women's experiences in Canada and the North of Europe. In particular, she has examined the nexus of colonialism and diverse forms of oppression. While the colonial or post-colonial situation is held by some scholars as prime explanation of diverse forms of oppression and inequality within indigenous communities (as implied by Eikjok), Kuokkanen argues that such a perspective is too short-handed: 'If gendered violence is recognized only as a consequence of the history of colonization of indigenous peoples at large, analyses will overlook indigenous women as victims of violence in their own right within their own communities' (Kuokkanen, 2015, p. 283). In other words, neither the acknowledgement of oppression and violence as a result of colonial power nor the oft-felt need that communities should speak with one voice (rather than expose internal differences) should serve as an excuse to leave women's views about their own social positions unaddressed. In this as well as many other regards, the concept of intersectionality helps to understand the multiple strands of marginalization - along categories of ethnicity, native language, class, age, and gender - which together produce the subjective experience of powerlessness (Hoogensen Gjørv, 2017; see also Anderson, Innes, \& Swift, 2012; Innes \& Anderson, 2015).

Thus one of the main contributions of Indigenous Feminists is in pointing out the necessity of analysis of dominant discourses and the social roles that they entail as a part of the effects that colonization has had in the regulations of gender in indigenous societies (Bettie, 2000; Hernández Rejón, 2016).

\section{Gender in relation to economy, resources, and nature}

Recent years have seen growing research on gendered economies in the Arctic. This section lays out the different threads that tie into this theme. First, an important topic in indigenous research in the Arctic since the 1990s has been female political leadership (Kulmala, 2010, 2014; Øverland \& Berg-Nordlie, 2012; Ssorin-Chaikov, 2003) as well as its economic implications (Konstantinov, 2005; Vladimirova, 2006). While earlier work on indigenous women's productive and reproductive activity should not be ignored, this can be considered an entry point for examining gendered economies in the Arctic, especially in its Russian part. This said, we do not imply that indigenous female political leadership is limited to instrumental or economic ends; rather, we want to explain its role in widening a field of study where the gendered aspects of indigenous and other economies in the North receive due attention. Even though work within this thematic framework has not directly engaged feminist geography, it shows similar theoretical concerns and overlapping areas of study.

Another strand that offers important input to the study of gendered economies is Feminist Political Ecology - one of the fields in geography that recently regained attention (Rocheleau, Thomas-Slayter, \& Wangari, 2013). It emphasizes gendered power relations in the 'ongoing rounds of accumulation, enclosure and dispossession' of existential resources (Elmhirst, 2011, p. 129). Feminist Political Ecology takes its momentum from Gender Studies to explore the connections between 'nature' and unequal access to its resources, the formation of a gendered subject, and the body. Of central interest are the gender dimensions of struggles over 'nature' and the environment, and how their study 
can contribute to female empowerment. In the context of Feminist Political Ecology the dominant conceptions of 'nature' and knowledge are revealed and questioned in order to open the space for study of marginal perspectives and stakeholders and to offer alternative epistemologies (Elmhirst, 2015). The conference on 'Gender Asymmetry and Resource Use in the Arctic' (Uppsala, February 2017), which gave rise to this special issue of Polar Geography, was inspired by these concerns and theoretical approaches. It emphasized different factors of human-environment relations and resource politics at their intersection with gender. A goal of the conference was to reveal the particular ways in which different Arctic regions currently experience gender shifts in the context of local historical, economic and environmental conditions. Further, we wanted to establish the global processes that trigger such changes and the diversity of ways in which they shape them in different localities.

Literature on gendered economy in the Arctic has already been mentioned earlier in this introduction in relation to other phenomena, such as the politics of tradition and identity. As we pointed out, interest in gendered economy is relatively new in the field of Arctic Studies, and it is marked by an immanent interest in intersectionality even when it is not explicitly stated. To be sure, female labor and subsistence activities were studied in previous decades; but with the growing interest in political leadership there is now a stronger, albeit still implicit, attention to the complexity and intersections between economic activities and other aspects of life, such as gender, ethnicity, social class and locality. Hugh Beach's above-mentioned works point out the gender inequality in Swedish Sámi reindeer herding communities (Beach, 1982, 2004, 2012, 2013, 2015; Beach \& Rasmussen, 2015) and explicate its economic aspects (cf. Eikjok, 2007; Kuokkanen, 2007). Further examination of economic strategies that include but are not limited to gendered relations over time, can be found in the work of Hovelsrud-Broda and Bodenhorn (Bodenhorn, 1988, 1993, 1997, 2012; Hovelsrud, Poppel, van Oort, \& Reist, 2011; Vom Bruck \& Bodenhorn, 2006).

The anthropological literature on migration in the North also offers insights on how the privileged development of certain economic branches exerts an immediate influence on men's and women's life strategies. Mineral resource extraction often creates temporary material and social structures and relies to a large extent on imported labor force. In Soviet time, industrial migration was informed by the idea of long-term occupation and generally of 'mastering' and 'civilising' the Arctic wilderness, i.e. in qualitative transformation. This created social transformations of a scale hardly experienced before. The increase in mixed marriages and the new employment possibilities are only a small part of this change, but one that has not received enough focus in research yet. At present, mine and oil workers are becoming predominantly short-term immigrants or even commuters and shift-workers. In some cases, they are residents of previous Soviet republics in Central Asia and elsewhere, who sustain their families 'back home'. This phenomenon triggers new social processes with equally long-term consequences for the residents of Arctic regions. In recent years, Gertrude Saxinger and her co-authors have paid special attention on extractive industry and its economic effects and the working force that it uses (Saxinger et al., 2016). Also, rather recently, the male aspect of hunting and herding has been complemented with a fresh perspective on the role of women in animal husbandry, notably with regard to cattle breeding in Sakha (Yakutia) (Stammler, 2010). There is considerable potential for the study of gender-species intersectionality 
in Arctic research (cf. Hovorka, 2012), thus reinvigorating the long-standing research interest in human-animal relations.

Further topics of research that have contributed to our understanding of gender and economy in the Arctic are women's roles in religion and ritual (Vaté, 2005, 2016). Social and economic security have recently received increasing attention by scholars. State-organized social security and care have been a central topic in Rebecca Kay's and Michele Rivkin-Fish's work, for example (Kay, 2011, 2014; Rivkin-Fish, 2013). Yulian Konstantinov and Petia Mankova have looked into remoteness as a disadvantage, but also a resource in the maintenance of social and economic networks of security (Konstantinov, 2009; Mankova, 2018). The intersection of state-organized social security and kinship-based care is also among the subjects of this special issue, particularly in the contribution by Vladimirova, as will be laid out in the following section, introducing the four subsequent papers.

\section{Contributions to this special issue}

Vladislava Vladimirova looks at the possible choices that women take as mothers and wives in a Nenets nomadic reindeer-herding community. She shows how institutions of care that are located in family and kinship relations and thought of as traditional, and state provided social security, are not seen by Nenets women as excluding each other. By describing two diachronic narratives of family care she reveals that no simple evolution can be traced from pre-revolutionary to state-organized practices and ideologies of care, kinship and citizenship. Instead, state-initiated struggle against some kinship institutions, such as bridewealth and levirate, and the many innovations introduced by the state, including kindergartens, boarding schools, orphanages, and other provisions have created a complex landscape of opportunities and limitations, generally perceived as 'old' and 'new'. Indigenous people orient themselves within this landscape through their strategic choices. They improvise, experiment, and creatively combine in order to procure security and provide or receive care. The paper illustrates the negotiations with state bureaucracies, in the wider society and within the indigenous community and the family.

Elena Khlinovskaya Rockhill and Zoya Tarasova also examine modifications in norms of partnership and creation of families, but from a different angle. Starting from the observation that fostering was a rather common habit of social support, they argue that a growing tendency of individualist life-course projects went hand in hand with a profusely biological, or genetic, understanding of what offspring is, and what offspring should be like. New reproductive technologies allow for a higher degree of controlled biological relatedness and they reduce the uncertainties of natural conception. Rather than employing the older practice of fostering, conjugal units now more frequently assert their autonomy through careful, biologically informed family planning. Interestingly, this 'individualist' trend becomes fused with the idea that the Sakha nation needs to secure its future, which in some commentators' views requires a conscious effort in genetic terms. Parallels are discursively drawn with the Sakha horse, assumedly a unique breed that can cope with the extremely continental (cold and dry) conditions of the Republic of Sakha (Yakutia). Khlinovskaya Rockhill and Tarasova thus discern the processes at work behind a seemingly contradictory situation: the 'individualist' shift from extended-family towards 
nuclear-family life projects does not counter, but rather supports the idea of Sakha as a larger unit of collectivity.

Aimar Ventsel uses the trope of mastering the North (osvoenie Severa) as point of departure for his juxtaposition of proletarian and newer, softer forms of masculinity. Again using the example of Yakutsk, capital of the Republic of Sakha (Yakutia), he briefly portrays the history of resource extraction in this part of Siberia, arguing that the Soviet industrial workers' ethos, as far as men were concerned, combined heavy physical work with the ability to participate in heavy drinking, and physical violence was a legitimate expression of virility. The 1990s and also 2000s, he argues, were characterized by a peak in violent and criminal behavior of youth gangs and drunk fights; whereas the last five to ten years saw the emergence of softer and more diverse displays of masculinity. These are brought forward, on the one hand, by a shift in professional conditions, away from hard physical work and towards lucrative office jobs. On the other hand, state policies promoting a healthy lifestyle along with the city's strict limitations of alcohol trade (from 2 to $8 \mathrm{pm}$ ) also work towards new modes of expressing masculinity - self-controlled, sportive or even athletic, and less prone to violent outbreaks. As to the central parts of Yakutsk, playing with androgynous or other non-standard looks is also tolerated. Displays of proletarian masculinity are nowadays more likely to occur at the margins of the city. The emergence of more diverse and softer expressions of masculinity should not be mistaken as a shift in gender hierarchies, however. The division of responsibilities between women and men continues to follow the border between domestic sphere and breadwinning jobs.

Ventsel's case study thus complicates and partially contradicts the common statement that women have 'coped' better than men with economic transition and changing gender roles. With regard to the Circumpolar North women are often reported to have shown more 'success' in adapting and redefining their gendered positions and roles, whereas men seem more frequently to be kept in 'traditional' gender roles (e.g. Eikjok, 2007; see above). Ventsel's study, however, reveals that this very much depends on particular livelihoods and professional activities.

Above we mentioned the congruence of three gradients: central to remote; female to male; and cultivated to uncivilized. Perhaps a somewhat exaggerated diagnosis, it still holds true for wide parts of the Russian Far North: women pursue some activities of resource harvesting in the tundra and taiga, but generally they seem to be dependent on men for transportation. In this light, Yulian Konstantinov briefly mentions the amazed banter in several villages of Kola Peninsula (northwest Russia) about two women who traveled by boat down Ponoi River and, what is more, successfully repaired the boat's outboard engine on the way back upstream. The disbelief of Kola villagers illustrates the gendered quality of space. Perhaps with Sherry Ortner (1972, pp. 5-6) we may say that when scrutinizing stereotypes about gender in the rural parts of Kola Peninsula and elsewhere, 'we are up against something very stubborn'. In his article, Yulian Konstantinov argues that the dichotomy female/male is more than just a discursive construction maintained by urban elites to malign livelihoods in the periphery; rather, some activities are so clearly gendered that they appear to be natural - as something that goes without saying - by the very inhabitants of remote places. He exemplifies this by asking: Why are women so conspicuously underrepresented in hunting, and even more so when it comes to opportunistic or deliberate forms of illicit hunting (poaching)? The very 
thought of a woman carrying a weapon alone in the forest seems to be awkward or transgressive. Konstantinov's analysis offers a comparison between Kola Peninsula and Bulgaria. It prepares the ground for more case studies on the highly gendered character of certain types of resource use.

Again, different parts of the circumpolar North are likely to yield different answers. As of yet, social-scientific scholarship is still disparate; there are not many publications that address the circumpolar North in its entirety with a potential to identify regionally different trends (Anon., 2002; Beach \& Rasmussen, 2015; Kuokkanen, 2015; Larsen \& Fondahl, 2015; Oddsdóttir, Sigurðsson, Svandal, \& Árnadóttir, 2015; Williamson et al., 2004).

\section{Gender in the Arctic: an ongoing conversation}

To conclude, we concur with Canadian geographer Caroline Desbiens's statement: 'if feminist geographers are right that space and gender determine one another, we can presume that changes in spaces of everyday life brought about by settlement and urban development have impacted the structure of male-female relations within First Nations' (Desbiens, 2007, p. 365). During the last three or four decades, research on gender relations in indigenous communities has been drawing this link very explicitly, and we hope to have shown in this introduction that this statement pertains to the North of Russia in particular.

The study of gender shifts must take into account that environmental conditions themselves are shifting, too (Elmhirst, 2011). Volatile prices on world markets, demands for new resources, and infrastructure development are among the factors that alter the practical and symbolic value of Northern spaces. Moreover, rapid warming and other forms of unprecedented environmental change affect the livelihoods of indigenous as well as nonindigenous residents, again with gender-specific ways of responding to such change (Bunce, 2015; Crate \& Nuttall, 2009, p. 15; Hovelsrud et al. , 2011).

This is the place to sketch out some possible vectors in future research on gender in the Arctic. As of now, there already exist a number of studies that look into the factors that influence gendered mobilities and life strategies in smaller and larger communities in the circumpolar North (we have portrayed some of these). What should be more strongly pursued is a comparison across the North (and further, between the circumpolar North and the Global South) of exactly how work and social support, consumption, and social hierarchies are experienced as gendered. An intersectional approach will be indispensable in the analysis of these experiences (Hoogensen Gjørv, 2017), to be coupled with greater attention to the malleability and ambiguity of gender norms (Arnfred \& Bransholm Pedersen, 2015; Williamson, 2011) and to queer modes of (non-)identification with gender roles (for example, Driskill, Finley, Gilley, \& Lauria Morgensen, 2011; Løvold, 2014). This line of inquiry should include new social arrangements that emerge in response to changing gender roles and environmental conditions. Moreover, it is necessary to analyse more closely the economic and political mechanisms that induce and/or perpetuate gender asymmetries and reproduce gender-specific notions of space.

Research on subjectivities within Feminist Geography is likely to offer fresh theoretical insights to be applied and tested in the Arctic (Probyn, 2003). Complementary to the existing analyses on the causes and consequences of 'female flight' - the higher proportion of 
women in migration to larger settlements - there is a need for a closer study of the motivations and life strategies of those who stay, return, or commute to their home communities in rural areas, taking into account the qualities and affordances of purportedly peripheral places in a more nuanced way (Mankova, 2018). In addition, a post-structuralist analysis may receive further development in order to reveal the epistemological preconditions of the processes we observe. For example, the discussion on performativity in Feminist Geography and Anthropology can be a good starting point (Morris, 1995; Sharp, 2009). Konstantinov's contribution to the special issue offers an illustration of this, even though he does not explicitly use the notion of performativity. Further study of the history of ideas informing older academic traditions of Arctic research can be useful too, as our glimpse into Indigenous Feminist Study's criticism toward conventional academic work on Arctic people persuasively argues (see above).

The four articles presented in this issue offer distinctive entry points into this widereaching discussion, which the authors of this introduction were fortunate to be part of over the last ten years. Scientific workshops and conferences took place in Cesvaine (Latvia) in 2008, Tromsø (Norway) in 2014, Uppsala (Sweden) in 2015 and 2017, and Küstrinchen (Germany) in 2016. Initially, working group members shared a focus on genderrelated issues in indigenous communities of the North of Russia, but in the meantime, the ambit has been widened regionally and also thematically. A Working Group on 'Gender in the Arctic' has been established under the International Arctic Social Sciences Association, with a kick-off event in Umeå in 2017 and a workshop in Oulu in September 2018, which will examine the intersection of queer and indigenous experiences of marginalization. The acknowledgements below and the statement about funding organisations reflect the manifold inputs of international scientific organizations, institutional and individual supporters. Notwithstanding the gradual intensification of contacts across the different parts of the circumpolar North, we have argued that research on gender in the Arctic is still a fragmented field. One of the reasons is the continued existence of language barriers; another can be found in the differences in national academic conventions, for example with regard to Russia. The articles that follow - from different regions within the Russian Federation will hopefully inform further research across the North.

\section{Acknowledgements}

Our gratitude goes first and foremost to the inhabitants of several communities across the North that met us with generosity, introduced us to their everyday lives, shared their concerns, expectations and ambitions, and discussed with us their views on gender-related issues. Debates with colleagues working in different social sciences and humanities added multiple facets. Many of them participated in one or several of the workshops mentioned above. We would like to thank Hugh Beach, Stephan Dudeck, Gunhild Hoogensen Gjørv, Yulian Konstantinov, Petia Mankova, Olga Povoroznyuk, Gertrude Saxinger, and Virginie Vaté for many years of cooperation and their commitment as workshop/conference co-conveners. Finally, we would like to thank two anonymous reviewers for their valuable comments, and Jessica Graybill and Tim Heleniak for making this special issue possible.

\section{Disclosure statement}

No potential conflict of interest was reported by the authors. 


\section{Funding}

We are grateful to the Research Council of Norway, the International Arctic Science Committee, Tromsø Research Foundation, the Center for Women's and Gender Studies (KVINNFORSK) at UiT - The Arctic University of Norway, Uppsala University, the Swedish Research Council (Vetenskapsrådet), the Riksbanken Jubileumsfond, the Max Planck Institute for Social Anthropology, and the Wenner-Gren Foundation for their financial and moral support.

\section{ORCID}

Vladislava Vladimirova (D) http://orcid.org/0000-0002-2594-9912

\section{References}

Anderson, K., Innes, R., \& Swift, J. (2012). Indigenous masculinities: Carrying the bones of the ancestors. In C. J. Greig \& W. J. Martino (Eds.), Canadian men and masculinities: Historical and contemporary perspectives (pp. 266-284). Toronto: Canadian Scholars' Press.

Anderson, M. (1987). The division of production, distribution and consumption in Saami society. Ethnos, 52(1-2), 8-27.

Anon. (2002). Taking wing: Conference report, conference on gender equality and women in the Arctic. 3-6 August 2002, Saariselkä, Inari, Finland. Helsinki: Ministry of Social Affairs and Health. Retrieved from https://oaarchive.arctic-council.org/bitstream/handle/11374/2074/ TakingWind_conference_report.pdf

Arnfred, S., \& Bransholm Pedersen, K. (2015). From female shamans to Danish housewives: Colonial constructions of gender in Greenland, 1721 to ca. 1970. NORA - Nordic Journal of Feminist and Gender Research, 23(4), 282-302.

Balzer, M. M. (1981). Rituals of gender identity: Markers of Siberian Khanty ethnicity, status, and belief. American Anthropologist, 83(4), 850-867.

Balzer, M. M. (1992). Russian traditional culture: Religion, gender and customary law. Armonk, NY: M. E. Sharpe.

Balzer, M. M. (1996). Sacred genders in Siberia: Shamans, bear festivals, and androgyny. In G. Harvey (Ed.), Shamanism: A reader (pp. 242-261). London: Routledge.

Balzer, M. M. (1999). The tenacity of ethnicity: A Siberian saga in global perspective. Princeton, NJ: Princeton University Press.

Beach, H. (1982). The place of women in the modern Saameby: An issue in legal anthropology. In M. Elg (Ed.), Antropologisk forskning (pp. 127-142). Svenska Sällskapet för Antropologi och Geographi. Motala: Borgström. (Ymer, vol. 102).

Beach, H. (2004). Political ecology in Swedish Saamiland. In M. Nuttall \& D. Anderson (Eds.), Cultivating Arctic landscapes: Knowing and managing animals in the Circumpolar North (pp. 110-123). New York, NY: Berghahn.

Beach, H. (2012). Nordic reflections on Northern social research. In U. Kockel, M. N. Craith, \& J. Frykman (Eds.), A companion to the anthropology of Europe (pp. 32-50). Chicester: Wiley Blackwell.

Beach, H. (2013). Devitalization and revitalization of traditional Saami dwellings in Sweden. In R. Wishardt, V. Vaté, \& D. Anderson (Eds.), About the hearth: Perspectives on the home, hearth and household in the circumpolar North (pp. 269-313). Oxford: Berghahn.

Beach, H. (2015). Nordic reindeer governance in the context of contemporary protected areas and species. In J. N. Larsen \& G. Fondahl (Eds.), Arctic human development report: Regional process, global linkages (pp. 269-313). Copenhagen: Nordic Council of Ministers.

Beach, H., \& Rasmussen, R. (2015). How might gender matter? In B. Poppel (Ed.), SLiCA: Arctic living conditions and quality of life among Inuit, Saami and indigenous peoples of Chukotka and the Kola Peninsula (pp. 360-384). Copenhagen: Nordic Council of Ministers. 
Bettie, J. (2000). Women without class: Chicas, cholas, trash, and the presence/absence of class identity. Signs: Journal of Women in Culture and Society, 26(1), 1-35.

Bloch, A. (2003). Red ties and residential school: Indigenous Siberians in a Post-Soviet state. Philadelphia: University of Pennsylvania Press.

Bloch, A. (2005). Longing for the Kollektiv: Gender, power, and residential schools in central Siberia. Cultural Anthropology, 20(4), 534-569.

Bloom, L., Glasberg, E., \& Kay, L. (2008). Gender on ice: Introduction. Scholar and Feminist Online (Barnard Center for Research on Women), 7(1), Item 1. Retrieved from http://sfonline.barnard. edu/ice/intro_01.htm

Bodenhorn, B. (1990). “I'm not the great hunter, my wife is": Iñupiat and anthropological models of gender. Études/Inuit/Studies, 14(1-2), 55-74.

Bodenhorn, B. (1993). Gendered spaces, public places: Public and private revisited on the North Slope of Alaska. Landscape: Politics and perspectives. Providence: Berg.

Bodenhorn, B. (1997). Person, place, and parentage: Ecology, identity, and social relations on the North Slope of Alaska. In S. A. Mousalimas, B. Munkácsi, O. von Sadovszky, \& M. Hoppál (Eds.), Arctic ecology and identity (pp. 103-132). Budapest: Akadémiai Kiadó.

Bodenhorn, B. (2012). On the road again: Movement, marriage, mestizaje and the race of kinship. In F. Cannell \& S. McKinnon (Eds.), Vital relations: Towards a 21st century anthropology (pp. 142-165). Santa Fe, NM: SAR Press.

Bodenhorn, B. A. (1988). Documenting Iñupiat family relationships in changing times. Report prepared for the North Slope Borough Iñupiaq History, Language and Culture Commission. Barrow: North Slope Borough Iñupiaq History, Language and Culture Commission.

Bourdieu, P. (1979). The Kabyle house or the world reversed. In P. Bourdieu (Ed.), Algeria 1960: Essays by Pierre Bourdieu (R. Nice, Trans.) (pp. 133-153). Cambridge: Cambridge University Press.

Bravo, M., \& Sörlin, S. (2002). Narrative and practice - an introduction. In M. Bravo \& S. Sörlin (Eds.), Narrating the Arctic: A cultural history of Nordic scientific practices (pp. 3-32). Canton, MA: Watson Publising International.

Bunce, A. (2015). Gender and the human dimensions of climate change: Global discourse and local perspectives from the Canadian Arctic (MA thesis). Department of Geography, McGill University, Montréal. Retrieved from http://climatechangenunavut.ca/sites/default/files/ 260325339_bunce_anna_geography_thesis_1.pdf

Crate, S. A., \& Nuttall, M. (2009). Introduction: Anthropology and climate change. In S. Crate \& M. Nuttall (Eds.), Anthropology and climate change: From encounters to actions (pp. 9-36). London: Berghahn.

Dahlström, K. (1996). Young women in a male periphery: Experiences from the Scandinavian North. Journal of Rural Studies, 12(3), 259-271.

Desbiens, C. (2007). Speaking the land: Exploring women's historical geographies in Northern Québec. The Canadian Geographer / Le Géographe Canadien, 51(3), 360-372.

Doel, R. E., Friedman, R. M., Lajus, J., Sörlin, S., \& Wråkberg, U. (2014). Strategic Arctic science: National interests in building natural knowledge - interwar era through the Cold War). Journal of Historical Geography, 44, 60-80.

Domosh, M. (1991). Toward a feminist historiography of geography. Transactions of the Institute of British Geographers, 16, 95-104.

Dowsley, M., \& Southcott, C. (2017). An initial exploration of whether 'female flight' is a demographic problem in Eastern Canadian Arctic Inuit communities. Polar Geography, 40(1), 1-18.

Driskill, Q.-L., Finley, C., Gilley, B. J., \& Lauria Morgensen, S. (2011). Introduction. In Q.-L. Driskill, C. Finley, B. J. Gilley, \& S. Lauria Morgensen (Eds.), Queer indigenous studies: Critical interventions in theory, politics, and literature (pp. 1-28). Tucson: University of Arizona Press.

Edwards, W. (2009). Introduction: Migration in northern Russia and Alaska. Polar Geography, 32 $(1-2), 1-1$.

Eikjok, J. (2007). Gender, essentialism and feminism in Samiland. In J. Green (Ed.), Making space for indigenous feminism (pp. 108-123). London: Zed Books. 
Elmhirst, R. (2011). Introducing new feminist political ecologies. Geoforum, 42(2), 129-132.

Elmhirst, R. (2015). Feminist political ecology. In A. Coles, L. Gray, \& J. Momsen (Eds.), The Routledge handbook of gender and development (pp. 82-90). London: Routledge.

Engels, F. (1902). The origin of the family, private property and the state (E. Untermann, Trans.). Chicago, IL: C. H. Kerr \& Company.

Fondahl, G. A. (1998). Gaining ground?: Evenkis, land and reform in southeastern Siberia. Boston, MA: Allyn and Bacon.

Frank, S. (2011). Teplaia Arktika: k istorii odnogo starogo literaturnogo motiva [The Warm Arctic: On the history of an ancient literary motif]. Novoe Literaturnoe Obozrenie, 2011(108), 82-97.

Friedman, R., \& Healey, D. (2002). Conclusions. In B. Clements, R. Friedman, \& D. Healey (Eds.), Russian masculinities in history and culture (pp. 223-235). London: Palgrave Macmillan.

Gernet, K. (2012). Vom Bleiben in Zeiten globaler Mobilität: Räume und Spielräume der Lebensgestaltung junger indigener Frauen im russischen Norden [On staying in times of global mobility: Spaces and agency of pursuing one's life projects among young women in the Russian North]. Frankfurt: P. Lang.

Gray, P. (2005). The Predicament of Chukotka's Indigenous movement. Post-soviet activism in the Russian Far North. Cambridge: Cambridge University Press.

Green, J. (Ed.). (2007). Making space for indigenous feminism. London: Zed Books.

Habeck, J. O. (2005a). What it means to be a herdsman: The practice and image of reindeer husbandry among [the] Komi of Northern Russia. Münster: Lit Verlag.

Habeck, J. O. (2005b). Gender and kul'tura at the Siberian and northern Russian frontier. In H. Haukanes \& F. Pine (Eds.), Generations, kinship and care: Gendered provisions of social security in Central Eastern Europe (pp. 189-206). Bergen: University of Bergen, Centre for Women's and Gender Research.

Hamilton, L. C., Rasmussen, R. O., Flanders, N. E., \& Seyfrit, C. L. (1996). Outmigration and gender balance in Greenland. Arctic Anthropology, 33(1), 89-97.

Hamilton, L. C., \& Seyfrit, C. L. (1993). Female flight? Gender balance and outmigration by native Alaskan villagers. Arctic Medical Journal, 53(Suppl. 2), 189-193.

Heleniak, T. (2015). Arctic populations and migration. In J. L. Larsen \& G. Fondahl (Eds.), Arctic human development report: Regional processes and global linkages (pp. 53-104). Copenhagen: Nordic Council of Ministers.

Hernández Rejón, M. (2016). Like Sámis do: A postcolonial and intersectional analysis of the contemporary film representations and self-representations of the Sámi people (Master thesis). Faculty of Humanities, Stockholm University. Retrieved from http://www.diva-portal.org/ smash/record.jsf?pid $=$ diva2\%3A940318\&dswid $=2122$

Hoogensen Gjørv, G. (2017). Finding gender in the Arctic: A call to intersectionality and diverse methods. In K. Latola \& H. Savela (Eds.), The interconnected Arctic - UArctic congress 2016 (pp. 293-303). Cham: Springer.

Hovelsrud, G. K., Poppel, B., van Oort, B., \& Reist, J. D. (2011). Arctic societies, cultures, and peoples in a changing cryosphere. Ambio, 40(Suppl. 1), 100-110.

Hovorka, A. J. (2012). Women/chickens vs. men/cattle: Insights on gender-species intersectionality. Geoforum, 43(4), 875-884.

Huskey, L., \& Howe, L. (2006). The complex geography of native migration in Arctic Alaska. In L. Huskey \& C. Southcott (Eds.), Migration in the circumpolar North: Issues and contexts (pp. 1534). Edmonton: CCI Press.

Innes, R. A., \& Anderson, K. (2015). Who's walking with our brothers? In R. A. Innes \& K. Anderson (Eds.), Indigenous men and masculinities: Legacies, identities, regeneration (pp. 79). Winnipeg: University of Manitoba Press.

Istomin, K. (2012). Once again on the problem of alcoholism and suicide among the Indigenous peoples of the Russian North: Can attribution style be a factor? Sibirica, 11(3), 1-19.

Josh Snodgrass, J. (2013). Health of indigenous circumpolar populations. Annual Review of Anthropology, 42, 69-87.

Kay, R. (2011). (Un) caring communities: Processes of marginalisation and access to formal and informal care and assistance in rural Russia. Journal of Rural Studies, 27(1), 45-53. 
Kay, R. (2014). Relationships, practices, and images of the local state in rural Russia. Social Analysis, 58(3), 56-72.

Kerttula, A. M. (2000). Antler on the sea: The Yup'ik and Chukchi of the Russian Far East. Ithaca, NY: Cornell University Press.

Khomich, L. V. (1950). Nenetskaia zhenshchina do i posle Oktiabr'skoi socialisticheskoi revoliutsii [Nenets woman before and after the socialist October Revolution] (PhD thesis). Leningrad State University, Leningrad.

Khomich, L. V. (1985). Brak i sem'ia u nentsev: traditsiia i sovremennost' [Marriage and family among nenets people: Tradition and present]. In G. P. Vasil'evaet al. (Eds.), Tezisy dokladov Vsesoiuznoi nauchnoi konferentsii "Semia u narodov SSSR $v$ usloviiakh razvitogo sotsialisticheskogo obshchestva”, 24-26 oktiabria 1985g. (pp. 235-237). Makhachkala: Institut etnografii im. N. N. Miklukho-Maklaia.

Konstantinov, Y. (2005). Reindeer-herders: Field-notes from the Kola Peninsula, 1994-95. Uppsala: Uppsala universitet.

Konstantinov, Y. (2009). Roadlessness and the person: Modes of travel in the reindeer herding part of Kola Peninsula. Acta Borealia, 26(1), 27-49.

Konstantinov, Y. (2015). Conversations with power: Soviet and postsoviet developments in the reindeer husbandry part of the Kola Peninsula. Uppsala: Uppsala University.

Kulmala, M. (2010). Women rule this country: Women's community organizing and care in rural Karelia. Anthropology of East Europe Review, 28(2), 164-185.

Kulmala, M. (2014). Karelian women's network: A (feminist) women's movement? In A. Saarinen, K. Ekonen, \& V. Uspenskaia (Eds.), Women and transformation in Russia (pp. 163-188). London: Routledge.

Kuokkanen, R. (2007). Myths and realities of Sami women: A post-colonial feminist analysis for the decolonization and transformation of Sami society. In J. Green (Ed.), Making space for Indigenous feminism (pp. 72-92). London: Zed Books.

Kuokkanen, R. (2015). Gendered violence and politics in Indigenous communities. International Feminist Journal of Politics, 17(2), 271-288.

Kuoljok, K. E. (1985). The revolution in the North. Soviet ethnography and nationality policy. Uppsala: Uppsala Universitet.

Kwon, H. (1997). Movements and transgressions: Human landscape in northeastern Sakhalin. In S. A. Mousalimas (Ed.), Arctic ecology and identity (pp. 143-168). Fullerton: International Society for Trans-Oceanic Research.

Laliberte, N., Driscoll-Derickson, K., \& Dowler, L. (2017). Advancements in feminist thought: Geography's contribution to international studies. In M. Balikov (Ed.), Oxford research encyclopedia of international studies (online edition). Retrieved from http://internationalstudies. oxfordre.com/view/10.1093/acrefore/9780190846626.001.0001/acrefore-9780190846626-e-116? rskey $=\mathrm{uKNFju \& result}=1$

Larsen, J. N., \& Fondahl, G. (2015). Arctic human development report: Regional processes and global linkages. Copenhagen: Nordic Council of Ministers.

Leacock, E. (1983). Interpreting the origins of gender inequality: Conceptual and historical problems. Dialectical Anthropology, 7(4), 263-284.

Liarskaya, E. (2009). Settlement Nenets on the Yamal Peninsula: Who are they? Folklore: Electronic Journal of Folklore, 41, 33-46.

Liarskaya, E. (2010). Women and the tundra: Is there a gender shift on Yamal? Anthropology of East Europe Review, 28(2), 51-84.

Liarskaya, E. (2013). Boarding school on Yamal: History of development and current situation. In E. Kasten \& T. de Graaf (Eds.), Sustaining Indigenous knowledge: Learning tools and community initiatives for preserving endangered languages and local cultural heritage (pp. 159-180). Fürstenberg: SEC Publications, Verlag der Kulturstiftung Sibirien.

Løvold, A. H. H. (2014). The Silence in Sápmi - and the Queer Sami Breaking It (PhD thesis). UiT The Arctic University of Norway, Tromsø. Retrieved from https://munin.uit.no/bitstream/ handle/10037/7063/thesis.pdf 
Luk'ianchenko, T. I. (1971). Material'naia kul'tura saamov (loparei) Kol'skogo poluostrova v kontse XIX-XX v. [Material culture of the Kola Saami (Lopars) at the end of the 19th and the 20th century]. Moscow: Nauka.

Mankova, P. (2018). Homewarding remoteness: Representations, agency and everyday life in a tundra village (NW Russia) (PhD thesis). UiT - The Arctic University of Norway, Tromsø. Retrieved from https://munin.uit.no/bitstream/handle/10037/12107/thesis.pdf

Massey, D. (1994). Space, place and gender. Cambridge: Polity Press.

McCauley, M. (2014). The Khrushchev Era 1953-1964. London: Routledge.

Moore, H. (1988). Feminism and anthropology. Cambridge: Polity Press.

Morgen, S. (Ed.). (1989). Gender and anthropology: Critical reviews for research and teaching. Washington, DC: Amer Anthropological Association.

Morris, R. C. (1995). All made up: Performance theory and the new anthropology of sex and gender. Annual Review of Anthropology, 24(1), 567-592.

Oddsdóttir, E. E., Sigurðsson, A. M., Svandal, S., \& Árnadóttir, A. K. (2015). Gender equality in the Arctic: Current realities, future challenges. Conference report. Reykjavík: Ministry for Foreign Affairs. Retrieved from https://oaarchive.arctic-council.org/handle/11374/409

Omma, L., Sandlund, M., \& Jacobsson, L. (2013). Suicidal expressions in young Swedish Sami: A cross-sectional study. International Journal of Circumpolar Health, 72(1), 19862.

Ortner, S. (1972). Is female to male as nature is to culture? Feminist Studies, 1(2), 5-31.

Ortner, S. (1996). So, is female to male as nature is to culture? In S. Ortner (Ed.), Making gender: The politics and erotics of culture (pp. 173-180). Boston, MA: Beacon Press.

Øverland, I., \& Berg-Nordlie, M. (2012). Bridging divides: Ethno-political leadership among the Russian Sámi. New York, NY: Berghahn Books.

Pika, A., \& Bogoyavlensky, D. (1995). Yamal Peninsula: Oil and gas development and problems of demography and health among Indigenous populations. Arctic Anthropology, 32(2), 61-74.

Pika, A., Davis, E. W., \& Krupnik, I. I. (1993). The spatial-temporal dynamic of violent death among the native peoples of northern Russia. Arctic Anthropology, 30(2), 61-76.

Potter, R. A. (2007). Arctic spectacles: The frozen North in visual culture, 1818-1875. Seattle: University of Washington Press.

Povoroznyuk, O., Habeck, J. O., \& Vaté, V. (2010). Introduction: On the definition, theory, and practice of gender shift in the North of Russia. Anthropology of East Europe Review, 28(2), 1-37.

Probyn, E. (2003). The spatial imperative of subjectivity. In K. Anderson, M. Domosh, S. Pile, \& N. Thrift (Eds.), Handbook of cultural geography (pp. 290-299). London: SAGE.

Rasmussen, R. O. (2009). Gender and generation: Perspectives on ongoing social and environmental changes in the Arctic. Signs: Journal of Women in Culture and Society, 34(3), 524-532.

Reiter, R. (Ed.). (1975). Toward an anthropology of women. London: Monthly Review Press.

Rethmann, P. (2010). Tundra passages: History and gender in the Russian far East. University Park: Pennsylvania State University Press.

Richards, B. (2004). From respect to rights to entitlement, blocked aspirations and suicidal behavior. International Journal of Circumpolar Health, 63(Suppl. 1), 19-24.

Richter, B. S. (1997). Nature mastered by man: Ideology and water in the Soviet Union. Environment and History, 3, 69-96.

Rivkin-Fish, M. (2013). Conceptualizing feminist strategies for Russian reproductive politics: Abortion, surrogate motherhood, and family support after socialism. Signs: Journal of Women in Culture and Society, 38(3), 569-593.

Rocheleau, D., Thomas-Slayter, B., \& Wangari, E. (Eds.). (2013). Feminist political ecology: Global issues and local experience. London: Routledge.

Rosaldo, M. Z., Lamphere, L., \& Bamberger, J. (Eds.). (1974). Woman, culture, and society. Stanford: Stanford University Press.

Rosner, V. (2009). Gender and Polar studies: Mapping the terrain. Signs: Journal of Women in Culture and Society, 34(3), 489-494.

Sablin, I., \& Savelyeva, M. (2015). Interspatial gender asymmetries in early Soviet Siberia. Gender, Place \& Culture, 22(6), 801-816. 
Saxinger, G., Oefner, E., Shakirova, E., Ivanova, M., Yakovlev, M., \& Gareyev, E. (2016). Ready to go! The next generation of mobile highly skilled workforce in the Russian petroleum industry. The Extractive Industries and Society, 3(3), 627-639.

Schröder, I. (2016). Shaping Youth: Quest for moral education in a Mansi Summer Camp in Western Siberia (PhD dissertation). Martin-Luther-Universität Halle-Wittenberg, Halle.

Sharp, J. (2009). Geography and gender: What belongs to feminist geography? Emotion, power and change. Progress in Human Geography, 33(1), 74-80.

Slezkine, Y. (1994). Arctic mirrors: Russia and the small peoples of the North. Ithaca, NY: Cornell University Press.

Ssorin-Chaikov, N. V. (2003). The social life of the state in subarctic Siberia. Stanford, CA: Stanford University Press.

Stammler, F. (2010). Animal diversity and its social significance among Arctic pastoralists. In F. Stammler \& H. Takakura (Eds.), Good to eat, good to live with: Nomads and animals in Northern Eurasia and Africa (pp. 215-243). Sendai: Center for Northeast Asia Studies, Tohoku University.

Strathern, M. (1987). An awkward relationship: The case of feminism and anthropology. Signs: Journal of Women in Culture and Society, 12(2), 276-292.

Tuisku, T. (2001). The displacement of Nenets women from reindeer herding and the tundra in the Nenets Autonomous Okrug, northwestern Russia. Acta Borealia, 18(2), 41-60.

Vakhtin, N. (1992). Native peoples of the Russian Far north. London: ERIC, Minority Rights Group International.

Vasilevich, G. M. (1969). Evenki: Istoriko-etnograficheskie ocherki (XVIII-nachalo XXv.) [Evenki: Historical-ethnographic sketches (18th to early 20th century)]. Leningrad: Nauka.

Vaté, V. (2005). Kilvêi: The Chukchi spring festival in urban and rural contexts. In E. Kasten (Ed.), Rebuilding identities: Pathways to reform in Post-Soviet Siberia (pp. 39-62). Berlin: Reimer.

Vaté, V. (2016). Dwelling in the landscape among the reindeer herding Chukchis of Chukotka. In P. Jordan (Ed.), Landscape and culture in Northern Eurasia (pp. 135-160). London: Routledge.

Vitebsky, P. (2010). From materfamilias to dinner-lady: The administrative destruction of the reindeer herder's family life. Anthropology of East Europe Review, 28(2), 38-50.

Vitebsky, P., \& Wolfe, S. (2001). The separation of the sexes among Siberian reindeer herders. In A. Low \& S. Tremayne (Eds.), Sacred custodians of the Earth?: Women, sprituality, and the environment (pp. 81-94). Oxford: Berg.

Vladimirova, V. K. (2006). Just labor: Labor ethic in a post-soviet reindeer herding community. Uppsala: Uppsala Universitet.

Vom Bruck, G., \& Bodenhorn, B. (2006). The anthropology of names and naming. Cambridge: Cambridge University Press.

Walsh, D., Valestrand, H., Gerrard, S., \& Aure, M. (2013). Gendered mobilities in the North: Advancing an international comparative perspective. Norsk Geografisk Tidsskrift - Norwegian Journal of Geography, 67(5), 260-265.

Williamson, K. J. (2011). Inherit my heaven: Kalaallit gender relations. Nuuk: Naalakkersuisut/ Government of Greenland; Inussuk Arctic Journal.

Williamson, K. J., Hoogensen Gjørv, G. H., Lotherington, A. T., Hamilton, L., Savage, S., Koukarenko, N., ... Poppel, M. (2004). Gender issues. In N. Einarsson, J. N. Larsen, A. Nilsson, \& O. R. Young (Eds.), Arctic human development report (pp. 187-205). Akureyri: Stefansson Arctic Institute.

Ziker, J. P. (2010). Changing gender roles and economies in Taimyr. Anthropology of East Europe Review, 28(2), 102-119. 